\title{
Interactive Effects of HLA and GM Alleles on the Development of Alzheimer Disease
}

Janardan P. Pandey, PhD, Paul J. Nietert, PhD, Ronald T. Kothera, MS, Lisa L. Barnes, PhD, and David A. Bennett, MD

Neurol Genet 2021;7:e565. doi:10.1212/NXG.0000000000000565

\author{
Correspondence \\ Dr. Pandey \\ pandeyj@musc.edu
}

\section{Abstract}

\section{Objective}

We investigated whether particular immunoglobulin GM ( $\gamma$ marker) alleles-individually or epistatically with a known human leukocyte antigen (HLA) risk allele-were associated with the development of Alzheimer disease (AD).

\section{Methods}

Using a prospective cohort study design, we genotyped DNA samples from 209 African American (AA) and 638 European American (EA) participants for IgG1 (GM 3 and GM 17), IgG2 (GM 23+ and GM 23-), and HLA-DRB1 rs9271192 (A/C) alleles by TaqMan and rhAMP genotyping assays.

\section{Results}

In EA subjects, none of the GM or HLA alleles—individually or epistatically-were associated with time to development of AD. In AA subjects, GM and HLA alleles individually were not associated with time to development of $\mathrm{AD}$. However, there was a significant interaction: In the presence of GM 3 (i.e., GM 3/3 and GM 3/17 subjects), the presence of the HLA-C allele was associated with a 4-fold increase in the likelihood of developing $\mathrm{AD}$ compared with its absence (hazard ratio [HR] 4.17, 95\% CI, 1.28-13.58). In the absence of GM 3 (GM 17/17 subjects), however, the presence of the HLA-C allele was not associated with time to development of AD (HR 1.10, 95\% CI, 0.50-2.41).

\section{Conclusions}

These results show that particular GM and HLA alleles epistatically contribute to the development of $\mathrm{AD}$. 


\section{Glossary}

AA = African American; AD = Alzheimer disease; EA = European American; GWAS = Genome-wide association study; $\mathbf{H R}=$ hazard ratio; IGHG = immunoglobulin heavy chain G.

Late-onset Alzheimer disease $(\mathrm{AD})$ is a heritable, complex, and progressive brain disorder. Genome-wide association studies (GWAS) have identified numerous risk genes, but most of the heritability of $\mathrm{AD}$ remains unexplained, suggesting additional genes in its etiology. Many risk-conferring genes identified thus far are enriched in the immune system pathways. ${ }^{1}$ A major gene of the immune system - HLA-DRB1 — has been associated with $\mathrm{AD}$ by many studies, including the largest GWAS of $\mathrm{AD}$ to date. ${ }^{2}$ The C allele of single-nucleotide polymorphism (SNP) rs9271192 within HLA-DRB1 seems to be a strong risk factor for $\mathrm{AD} .^{3}$

The current GWAS of $\mathrm{AD}$ do not evaluate a major gene complex of the immune system-GM ( $\gamma$ marker) allotypes encoded by immunoglobulin heavy chain $\mathrm{G}$ (IGHG) genes on chromosome 14. ${ }^{4,5}$ The 3 IGHG genes that encode GM allotypes are highly homologous and apparently not amenable to high throughput genotyping technology used in GWAS. Therefore, a candidate gene approach is necessary to investigate the role of the immunoglobulin GM allotypes in the immunobiology of $\mathrm{AD}$. There is a good rationale for the GM gene involvement in the etiopathogenesis of $\mathrm{AD}$. These genes have been shown to influence the magnitude of antibody responses to various antigens. ${ }^{4,5}$ The presence of amyloid- $\beta$ $(\mathrm{A} \beta)$ plaques is one of the hallmarks of $\mathrm{AD}$. IgG heavy chains, where all GM allotypes are expressed, have inherent antiamyloidogenic activity. ${ }^{6}$ Thus, polymorphic GM genes could contribute to the interindividual differences in the level of antibody responses to $A \beta$, thereby influencing the pathogenesis of the disease.

In this study, we aimed to determine the individual and/or epistatic (defined as modification of the action of a gene by an allele at another locus) contribution of GM and HLA-DRB1 genotypes to the development of $\mathrm{AD}$.

\section{Methods}

\section{Study Design and Samples}

Using a prospective cohort study design, this investigation used archived DNA specimens and data from 3 longitudinal cohorts on aging: The Minority Aging Research Study, The Rush Memory and Aging Project, and The Religious Orders Study, which have been described in detail elsewhere. ${ }^{7,8}$

A stratified sampling scheme was used to select a subset of participants without dementia at baseline from each cohort. African American (AA) participants from all 3 studies were included $(n=209)$. A subset of European American (EA) participants was randomly selected from the 2 cohorts that are predominantly EA $(\mathrm{N}=638)$.

\section{Standard Protocol Approvals, Registrations, and Patient Consents}

The study was approved by Institutional Review Boards of Rush University Medical Center and Medical University of South Carolina. All participants signed an informed consent and a repository consent to allow their data to be repurposed.

\section{Data Availability}

Data can be requested at radc.rush.edu.

\section{GM Genotyping}

IgG1 markers GM 3 and 17 (arginine to lysine) and IgG2 markers GM 23- and 23+ (valine to methionine) were determined by a TaqMan genotyping assay from Applied Biosystems Inc.

\section{HLA-DRB1 rs9271192 Genotyping}

HLA-DRB1 SNP rs9271192 (A > C) was determined by a custom-designed rhAMP SNP genotyping assay from Integrated DNA Technologies Inc.

\section{Statistical Analysis}

Multivariable logistic regression was used to compare rates of $\mathrm{AD}$ and mortality during follow-up between EAs and AAs, while adjusting for baseline age and length of follow-up time. Associations between the candidate genes and time to development of $\mathrm{AD}$ were assessed using Cox proportional hazards $(\mathrm{PH})$ models, which accounted for mortality and loss to follow up. Models were developed separately for EAs and AAs, given that the allelic frequencies for GM and HLA vary considerably by race. Time to development of $\mathrm{AD}$ was modeled as a function of covariates (baseline age, sex, years of education, and APOE- 4 carrier status), the candidate genes, and gene $x$ gene interactions using a backwards model selection process. The covariates were forced into each model, regardless of statistical significance. For all models, the proportionality assumption was verified. No adjustment was made for multiple comparisons because this was largely a hypothesis generating exercise. Analyses were further stratified by sex to determine whether our findings were consistent for men and women. Analyses were conducted using SAS v9.4 (SAS Institute, Cary, NC).

\section{Results}

Table presents the descriptive statistics of EA and AA subjects. The proportion of subjects that developed $\mathrm{AD}$ during the follow-up was higher in EA than that in the AA group (37.3 vs $19.6 \%$ ), although this was not significant after adjusting for baseline age and length of follow-up time, which was higher among EAs than AAs (mean [SD]: 12.5 [4.6] vs 
Table Descriptive Statistics of Cohorts Stratified by Race

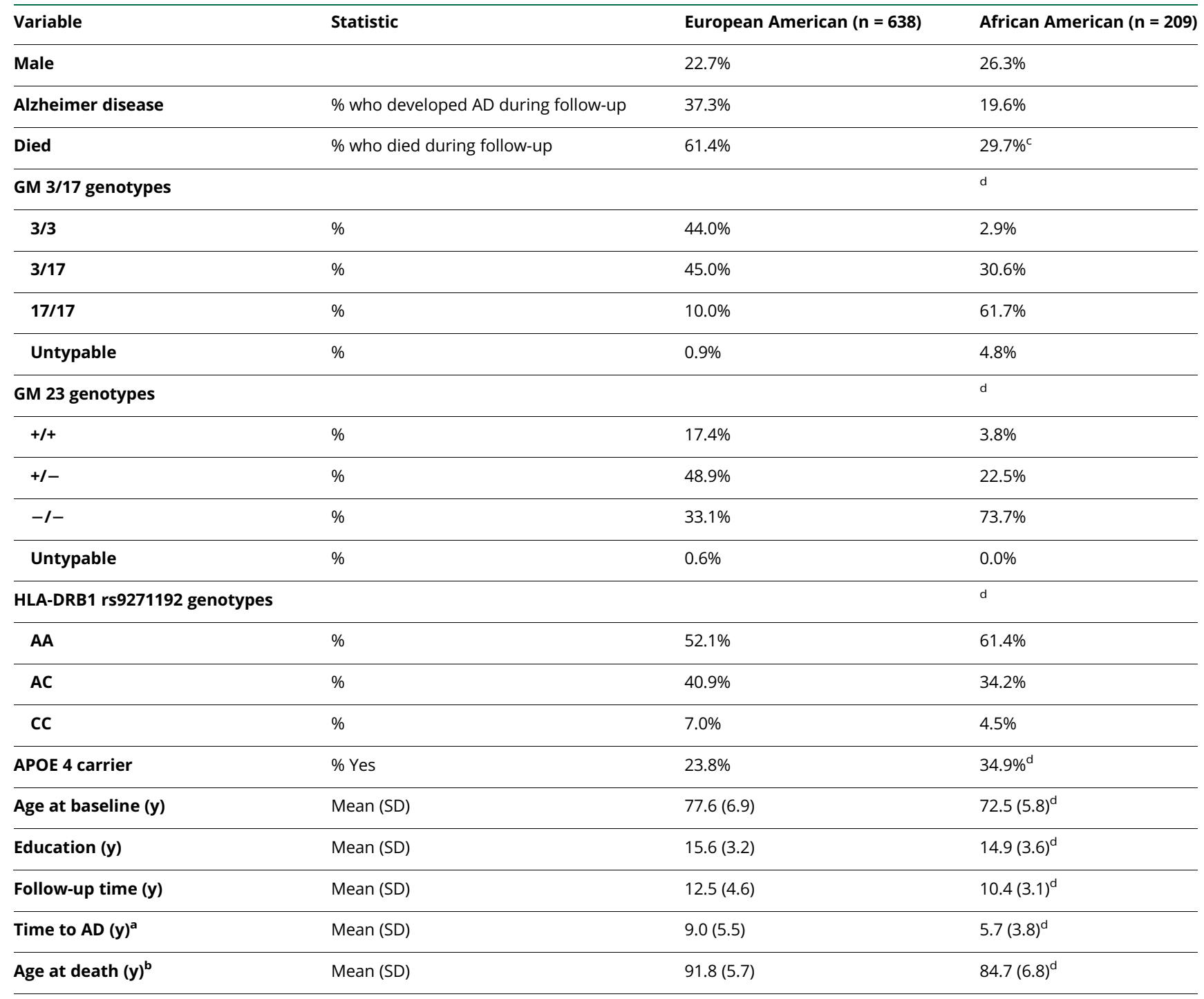

Abbreviations: $A A=$ African American; $A D=$ Alzheimer disease; $E A$ = European American.

${ }^{a}$ Among patients who developed $A D$ during the study time frame (EA: $\left.n=238, A A: 41\right)$.

${ }^{b}$ Among patients who died during the study time frame (EA: $n=392, A A: 62$ ).

${ }^{c} p<0.05$ when compared with EAs by logistic regression, after adjusting for age at baseline and follow-up time.

d $p<0.05$ when compared with EAs, by $\chi^{2}$ or Wilcoxon rank sum test, as appropriate.

10.4 [3.1], $p<0.05)$. In addition, a higher proportion of EA than AA subjects died during the follow-up (61.4 vs $30.0 \%)$. For all genes of interest, there were markedly different genotype distributions noted when comparing EAs to AAs ( $p<$ 0.05 for all comparisons).

In EA subjects, none of the GM or HLA alleles-individually or epistatically - were associated with time to development of $\mathrm{AD}$ (all $p$-values $>0.10$ ). In AA subjects, however, a different pattern emerged. When no gene by gene interactions were considered, GM and HLA alleles individually were not associated with time to development of $\mathrm{AD}$. However, when we included their interaction in the model, we identified a robust interaction. In the presence of GM 3 (i.e., GM 3/3 and GM $3 / 17$ subjects), the presence of the HLA-C allele was associated with a 4-fold increase in the likelihood of developing $\mathrm{AD}$ compared with its absence (hazard ratio [HR] 4.17, 95\% CI, 1.28-13.58, figure 1). In the absence of GM 3 (GM 17/17 subjects), however, the presence of the HLA-C allele was not associated with time to development of $\mathrm{AD}$ (HR 1.10, 95\% CI, 0.50-2.41, figure 2). Because the APOE-4 allele and other variables were used as covariates in these analyses, the interactive effect of GM and HLA genotypes on the development of $\mathrm{AD}$ was independent of the APOE-4 allele status and other subject covariates.

\section{Discussion}

The results presented here clearly show that in AA, the C allele of the rs9271192 SNP within HLA-DRB1 may be a strong risk factor for $\mathrm{AD}$ in presence of the immunoglobulin GM 3 allele. This association was not found for EA. As 
Figure 1 Proportion of African American Subjects Without Alzheimer Disease Over Time Among Subjects With the GM 3 Allele, Stratified by HLA C Status

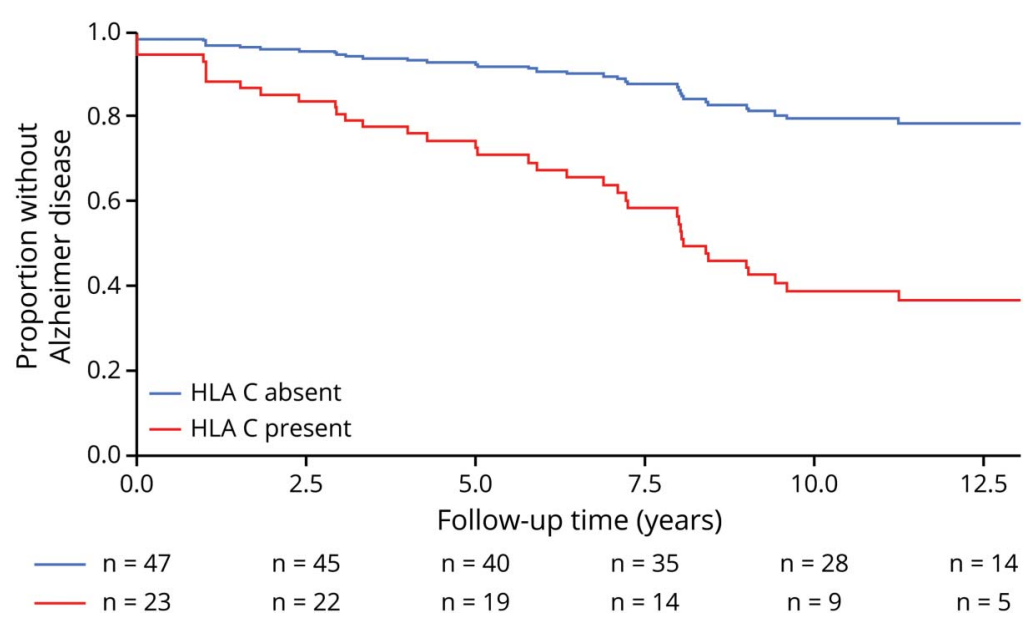

mentioned earlier, several studies have reported the association of the C allele of the HLA-DRB1 SNP with susceptibility to $\mathrm{AD}$. Because none of these studies genotyped for the GM gene complex, it is not possible to determine whether the HLA associations observed were independent of the GM genotype status of the subjects.

A possible mechanism of joint GM-HLA gene involvement in susceptibility to $\mathrm{AD}$ could be through their putative influence on antibody responses to $A \beta$ via HLA-DRB1-restricted antigen processing/presentation pathway. IgG heavy chains (which express GM allotypes) have been shown to have natural antiamyloidogenic properties. ${ }^{6}$ It is possible that the antigen presenting $B$ cells with the membrane-bound IgG expressing the GM 3 allotype are not effective recognition structures for the $A \beta$ peptides. Furthermore, these peptides may not fit properly in the peptide-binding groove of the atrisk HLA-DRB1 C allele, leading to inadequate presentation to the $\mathrm{CD} 4^{+} \mathrm{T}$ helper cells and the consequent lack of $\mathrm{B}$ cell activation to generate anti- $\mathrm{A} \beta$ antibodies.

The reasons for the observed racial differences in the contribution of GM and HLA alleles in the development of $\mathrm{AD}$ are not clear. Both GM and HLA allele frequencies differ significantly between AA and EA populations. These differences, together with other racially associated genetic and nongenetic factors relevant to the development of $\mathrm{AD}$, may have contributed to the differences observed in this investigation.

Although the phenomenon of epistasis has been known for over 100 years, ${ }^{9}$ there is a paucity of studies to detect possible epistatic interactions in human diseases. ${ }^{10}$ It is hoped that

Figure 2 Proportion of African American Subjects Without Alzheimer Disease Over Time Among Subjects Without the GM 3 Allele, Stratified by HLA C Status

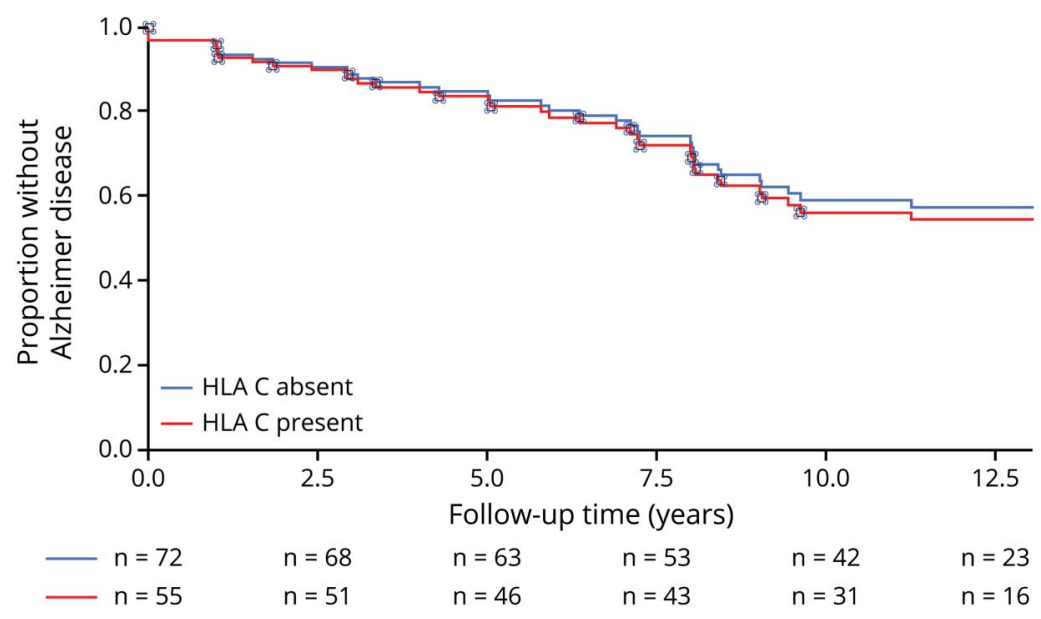


results presented here will inspire further investigations on gene-gene interactions in $\mathrm{AD}$ and other complex polygenic/ multifactorial diseases.

\section{Study Funding}

This work was supported in part by the NIH (NIA grant Nos. AG058489, AG10161, AG17917, AG22018, and NCATS grant No. UL1-TR001450).

\section{Disclosure}

Disclosures available: Neurology.org/NG.

\section{Publication History}

Received by Neurology: Genetics July 15, 2020. Accepted in final form December 22, 2020.

\section{Appendix Authors}

\begin{tabular}{|c|c|c|}
\hline Name & Location & Contribution \\
\hline $\begin{array}{l}\text { Janardan } \\
\text { P. Pandey, } \\
\text { PhD }\end{array}$ & $\begin{array}{l}\text { Medical University of } \\
\text { South Carolina, } \\
\text { Charleston }\end{array}$ & $\begin{array}{l}\text { Design and conceptualized the } \\
\text { study and drafted the manuscript } \\
\text { for intellectual content }\end{array}$ \\
\hline $\begin{array}{l}\text { Paul J. } \\
\text { Nietert, } \\
\text { PhD }\end{array}$ & $\begin{array}{l}\text { Medical University of } \\
\text { South Carolina, } \\
\text { Charleston }\end{array}$ & $\begin{array}{l}\text { Analyzed the data, and revised } \\
\text { the manuscript for intellectual } \\
\text { content }\end{array}$ \\
\hline $\begin{array}{l}\text { Ronald T. } \\
\text { Kothera, } \\
\text { MS }\end{array}$ & $\begin{array}{l}\text { Medical University of } \\
\text { South Carolina, } \\
\text { Charleston }\end{array}$ & Genotyped the DNA samples \\
\hline
\end{tabular}

Appendix (continued)

\begin{tabular}{lll}
\hline Name & Location & Contribution \\
\hline $\begin{array}{l}\text { Lisa L. } \\
\text { Barnes, } \\
\text { PhD }\end{array}$ & $\begin{array}{l}\text { Rush Alzheimer's } \\
\text { Disease Center, } \\
\text { Chicago, IL }\end{array}$ & $\begin{array}{l}\text { Design and conceptualized study } \\
\text { and revised the manuscript for } \\
\text { intellectual content }\end{array}$ \\
$\begin{array}{l}\text { David A. } \\
\begin{array}{l}\text { Bennett, } \\
\text { MD }\end{array}\end{array}$ & $\begin{array}{l}\text { Rush Alzheimer's } \\
\text { Disease Center, } \\
\text { Chicago, IL }\end{array}$ & $\begin{array}{l}\text { Design and conceptualized study } \\
\text { and revised the manuscript for } \\
\text { intellectual content }\end{array}$ \\
\hline
\end{tabular}

\section{References}

1. Wang N, Zhang Y, Xu L, Jin S. Relationship between Alzheimer's disease and the immune system: a meta-analysis of differentially expressed genes. Front Neurosci 2019;12:1026.

2. Jansen IE, Savage JE, Watanabe K, et al. Genome-wide meta-analysis identifies new loci and functional pathways influencing Alzheimer's disease risk. Nat Genet 2019;51: 404-413.

3. Lu RC, Yang W, Tan L, et al. Association of HLA-DRB1 polymorphism with Alzheimer's disease: a replication and meta-analysis. Oncotarget 2017;8: 93219-93226.

4. Oxelius VA, Pandey JP. Human immunoglobulin constant heavy G chain (IGHG) $(\mathrm{Fc} \gamma)(\mathrm{GM})$ genes, defining innate variants of IgG molecules and B cells, have impact on disease and therapy. Clin Immunol 2013;149:475-486.

5. Warrender AK, Kelton W. Beyond allotypes: the influence of allelic diversity in antibody constant domains. Front Immunol 2020;11:2016.

6. Adekar SP, Klyubin I, Macy S, et al. Inherent anti-amyloidogenic activity of human immunoglobulin gamma heavy chains. J Biol Chem 2010;285:1066-1074.

7. Barnes LL, Shah RC, Aggarwal NT, Bennett DA, Schneider JA. The Minority Aging Research Study: ongoing efforts to obtain brain donation in African Americans without dementia. Curr Alzheimer's Res 2012;9:734-745.

8. Bennett DA, Buchman AS, Boyle PA, Barnes LL, Wilson RS, Schneider JA. Religious orders study and rush memory and aging Project. J Alzheimer's Dis 2018;64:S161-S189.

9. Bateson W. Mendel's Principles of Heredity. Cambridge: Cambridge University Press; 1909.

10. Felsky D, Xu J, Chibnik LB, et al. Genetic epistasis regulates amyloid deposition in resilient aging. Alzheimers Dement 2017;13:1107-1116. 


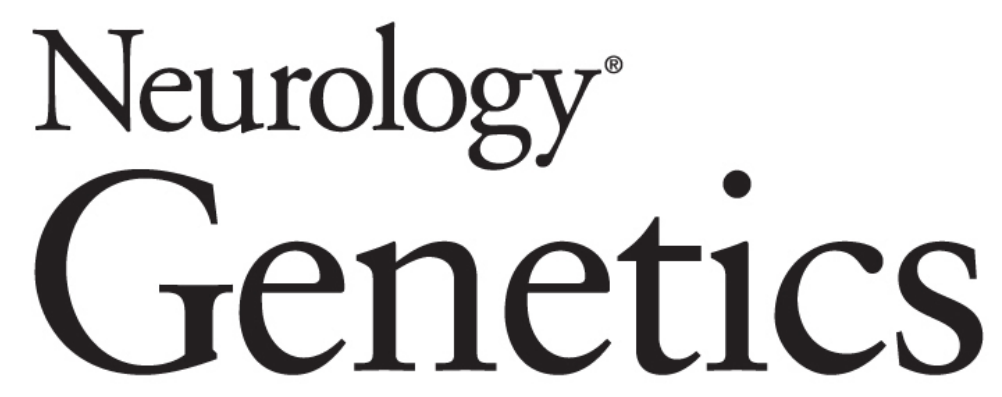

Interactive Effects of HLA and GM Alleles on the Development of Alzheimer Disease Janardan P. Pandey, Paul J. Nietert, Ronald T. Kothera, et al. Neurol Genet 2021;7;

DOI 10.1212/NXG.0000000000000565

This information is current as of February 16, 2021

Neurol Genet is an official journal of the American Academy of Neurology. Published since April 2015, it is an open-access, online-only, continuous publication journal. Copyright Copyright $(2021$ The Author(s). Published by Wolters Kluwer Health, Inc. on behalf of the American Academy of Neurology.. All rights reserved. Online ISSN: 2376-7839.

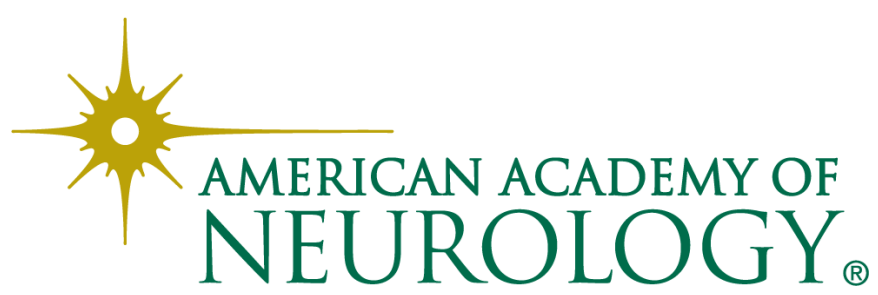




\section{Updated Information \& Services}

References

Subspecialty Collections

Permissions \& Licensing

\section{Reprints}

including high resolution figures, can be found at: http://ng.neurology.org/content/7/2/e565.full.html

This article cites 9 articles, 1 of which you can access for free at: http://ng.neurology.org/content/7/2/e565.full.html\#\#ref-list-1

This article, along with others on similar topics, appears in the following collection(s):

\section{All Genetics}

http://ng.neurology.org//cgi/collection/all_genetics

All Immunology

http://ng.neurology.org//cgi/collection/all_immunology

Alzheimer's disease

http://ng.neurology.org//cgi/collection/alzheimers_disease

Association studies in genetics

http://ng.neurology.org//cgi/collection/association_studies_in_genetics Risk factors in epidemiology

http://ng.neurology.org//cgi/collection/risk_factors_in_epidemiology

Information about reproducing this article in parts (figures,tables) or in its entirety can be found online at:

http://ng.neurology.org/misc/about.xhtml\#permissions

Information about ordering reprints can be found online:

http://ng.neurology.org/misc/addir.xhtml\#reprintsus

Neurol Genet is an official journal of the American Academy of Neurology. Published since April 2015, it is an open-access, online-only, continuous publication journal. Copyright Copyright $\odot 2021$ The Author(s). Published by Wolters Kluwer Health, Inc. on behalf of the American Academy of Neurology.. All rights reserved. Online ISSN: 2376-7839.

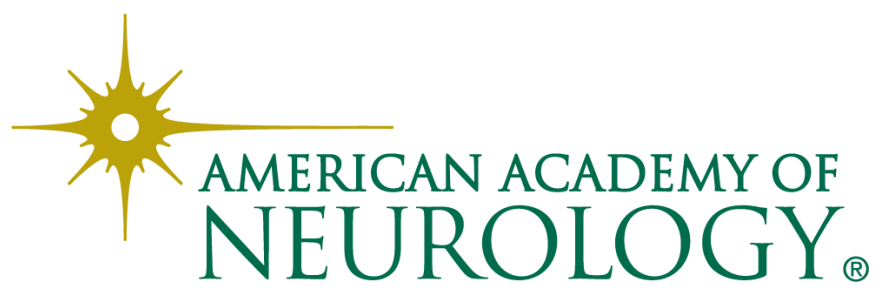

